\title{
Introduction of Electrocardiography
}

노태호, 장성원

가톨릭대학교 의과대학 내과학교실

Tai Ho Rho, MD; Sung-Won Jang, MD

Division of Cardiology, St. Paul's Hospital, Department of Internal Medicine, The Catholic University of Korea, Seoul, Republic of Korea
Received: April 11, 2017

Revision Received: May 25, 2017

Accepted: May 25, 2017

Correspondence: Tai Ho Rho, MD

St. Paul's Hospital, The Catholic University of Korea, 180 Wangsan-ro, Dongdaemun-gu, Seoul 02559, Republic of Korea

Tel: +82-2-958-2450 Fax: +82-2-968-7250

E-mail: tairho@catholic.ac.kr

\section{ABSTRACT}

In 1901, in a historic first, Willem Einthoven invented electrocardiography using a string galvanometer. He assigned the letters $\mathrm{P}, \mathrm{Q}, \mathrm{R}, \mathrm{S}$, and $\mathrm{T}$ to the major deflections and described electrocardiographic features of a number of cardiovascular disorders. Water pots that he initially used to record electrical signals from the skin were replaced with patchy electrodes later. These electrodes detect tiny electrical currents arising from the heart muscle during cardiac cycles. The tiny currents are amplified, filtered, and displayed to produce electrocardiographic recordings. The $\mathrm{P}$ wave is generated by depolarization of atria. The PR interval represents the duration of atrioventricular conduction, the QRS complex is produced by depolarization of both ventricles, and the ST-T wave reflects ventricular repolarization. Electrocardiography is essential to diagnose myocardial ischemia and various rhythm disorders. It has expanded its scope to include long-term monitoring, exercise tests, signal averaged electrocardiography, electrophysiologic studies, and three-dimensional electrocardiographic mapping system. Owing to these advances, electrocardiography now plays a critical role not only in diagnosis but also in the therapeutic fields of cardiac disease.

Key Words: - Electrocardiography

\section{서론}

1901년 Willem Einthoven에 의해 발명된 심전도는 거의 같은 시기에 발견된 X선과 함께 주로 청진기에만 의존하던 의사들과 환자들을 위해 매우 위대한 발견이었다. 당시의 심전도기는 매우 얇은 은 도금선을 강한 자기장 내에 위치시켜 심장에서 발생하는 약한 전류가 통과하면 자기장의
영향으로 선이 이동하게 되고, 이러한 운동을 초당 $25 \mathrm{~mm}$ 속도로 움직이는 사진판에 기록한 것으로 이 기준은 현재에도 적용되고 있다. 이러한 string galvanometer는 동정맥이나 심첨부의 변화 등으로 심부정맥을 연구하던 학자들에게 훌륭한 연구 수단을 제공하였고, Einthoven은 이미 1906년에 심방세동, 심실조기수축, 심방조동 등의 역사상 최초의 심전도를 발표하였다. 그뿐만 아니라 심전도의 파형에 P, Q, 


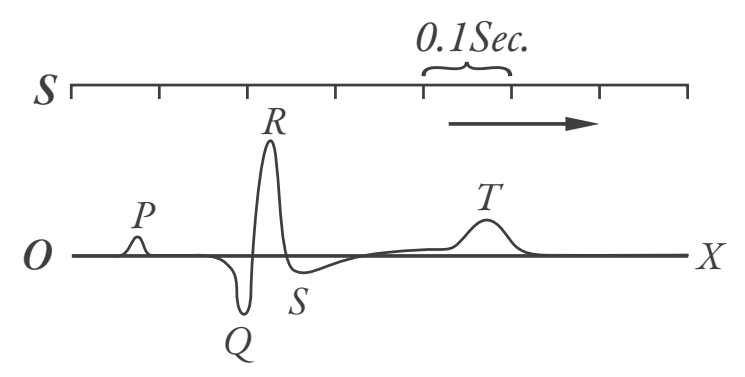

Figure 1. One of the first electrocardiographic recordings in Einthoven's era. Einthoven has assigned the letters $P, Q, R, S$, and $T$ to the major deflections of the recording.

R, S, T의 이름을 붙이기도 하였다(Figure 1).

심전도의 전파에 힘입어 가장 먼저 발달한 분야는 부정맥 연구 분야로 Shapiro는 심전도를 '부정맥의 로제타석 (Rosetta stone)'이라고 일컬었다. 1910년대에 Thomas Lewis 는 '심장박동의 기전', '심장박동의 질환' 등의 저서를 발표할 정도로 단기간에 큰 발전을 이루었고 당시에 이미 동방결절, 조기수축, 향도잡이, 발작성 빈맥 등의 용어와 개념이 성립되었다.

심전도의 임상 이용이 증가하면서 부정맥뿐만 아니라 심근경색증 시 심전도 변화도 알려지기 시작하였다. 1924년 Oppenheimer가 부검 결과와 심전도 소견을 근거로 관상동맥색전과 심전도 이상의 관련성을 보고하였다. 곧이어 1928년 Parkinson 등은 관상동맥 색전으로 인한 심근경색증 환자 28 례에서 심전도를 반복 검사한 결과 ST 분절의 상승이 수일에 걸쳐 회복되며, T파의 역전이 발생한다는 사실을 밝혔다. 또한 Feil 등은 협심증 환자에서 통증발생 시에 일시적으로 나타나는 ST 분절의 변화를 관찰하는 등 허혈성 심질환의 진단에 심전도가 갖는 중요성을 인식하였다. 심전도가 발명된 이래 3 사지유도만을 사용하던 당시 전형적인 심근경색증 환자 중 일부는 심전도 상에 전혀 이상소견을 보이지 않는 점을 이상하게 여긴 Wolferth 등이 앞가슴과 등에 전극을 부착하여 검사한 결과 이상소견을 발견하고, 단극유도(unipolar lead)가 소개된 후 1938년에 V 1 에서 $\mathrm{V}_{6}$ 의 흥부유도가 결정되어 현재까지 이르고 있다. ${ }^{1,2}$

그 후 과학기술의 발전과 더불어 적고 사용이 간편해진 심전도기, 생활심전도, 운동부하심전도, signal averaged $\mathrm{ECG}$, 임상 전기생리학 검사 등의 발달과정을 거쳐 광의의
심전도는 심장질환뿐만 아니라 여러 다른 장기의 질환, 대사 및 전해질 이상의 진단과 이해에 필수적인 도구로 자리 잡고 있다.

\section{심장의 전기발생}

생명 현상의 근원인 심장박동은 심장에서 발생하는 전기를 매개로 하며 이 전기의 발원은 동방결절이다. 동방결절은 해부학적으로 우심방의 sulcus terminalis의 후상표면에 위치하고 $25 \mathrm{~mm}$ 의 길이를 갖는다고 알려져 왔으나, 실제 기능상 주요 부위는 그리 명확히 한계되지는 않는다. 주된 향도잡이 세포는 동방결절 내에서도 일부분만을 차지하며 electron microscopy (EM)상의 특징적인 모양으로 P cell로 명명되었다. 종래에는 많은 향도잡이 세포 중에서 가장 빠른 탈분극 속도를 갖는 극소수 혹은 한 세포에 의해 다른 여러 세포들이 overdrive suppression이 되고, 결국 이 극소수의 세포가 주된 향도잡이 역할을 한다고 믿었다. 그러나 근래에는 그보다는 많은 세포 혹은 세포군이 약간 다른 탈분극 속도를 갖고 있음에도 불구하고, 서로 전기적으로 혹은 direct electrical coupling에 의해 영향을 미쳐 일정한 consensus rate를 갖게 된다고 알려졌다. 동방결절 세포는 심장 내 여타 세포와 달리 스스로 전기를 발생시키는데, 이는 이완기에 세포막전위가 외부 자극 없이 서서히 탈분극 할 수 있는 고유한 능력을 갖고 있기 때문이다. 이렇게 특이한 탈분극 현상은 전이완기에 걸쳐 외향성 전류를 형성하여 재분극시키는 역할을 하는 delayed rectifier current $\left(I_{\mathrm{K}}\right)$ 가 이완초기에 급속히 붕괴(dacay)되며, 동시에 과분극 시 활성화되는 내향성 전류인 If의 역할로 탈분극이 시작되고 곧 이어 내향성 $\mathrm{L}^{\text {형 }} \mathrm{Ca}^{2+}$ 전류 $\left(\mathrm{I}_{\mathrm{Ca}}\right)$ 가 탈분극을 완성시킨다. 이러한 탈분극은 여러 주변의 상황 변화, 즉 자율신경계나 전해질 변화에 따라 크게 영향을 받는다. 부교감신경자극은 $I_{\mathrm{Ca}}$ 를 감소 또는 $\mathrm{K}^{+}$투과를 항진시키거나 $I_{\mathrm{f}}$ 를 감소시켜 탈분극률을 낮추어 심박수를 감소시킨다. 반면에 교감신경자극은 $I_{\mathrm{K}}, I_{\mathrm{f}}, I_{\mathrm{Ca}}$ 를 증가시켜 탈분극률과 심박수를 증가시킨다. ${ }^{3}$

동방결절의 탈분극은 심전도 상 $\mathrm{P}$ 파가 나타나기 직전에 발생하는 전기현상으로 체표 심전도로 인지가 불가능하다. 그러나 심장 내에 전극도자를 삽입하여 동방결절 위에 접근시켜 동방결절 전기도를 얻을 수 있으며, 이 방법은 
동방전도시간(sinoatrial conduction time, SACT)을 측정하는 데 사용될 수 있다.

\section{심장의 전기흐름과 심전도의 형성}

\section{1) 심방의 전기흐름}

동방결절을 벗어난 전기파는 심방으로 전파되는데, 심방의 복잡한 해부학적 구조로 인하여 전도가 그리 균일하지는 않다. 개에서는 우심방의 전도가 모두 이루어지는데, 30-40 $\mathrm{ms}$ 가 걸리고, 전기전파는 균일하지 않아 crista terminalis 따라 상하 방향으로 가장 빨리 $1.0 \mathrm{~ms}$ 의 속도로 전도되며, appendage가 가장 늦게 활성화된다. 전기파가 동방결절에서 나오고 10-30 ms의 속도로 좌심방에 도달한다. 좌심방에서 한 전기파는 심방 전면의 Bachmann속을 따라 빨리 전도하고 다른 파는 중격을 통해 천천히 전도하여 이 두 전도파는 좌심방 후면에서 50-70 ms에 만나게 된다. 사람에서도 같은 양상의 전도가 이루어지며 전도시간은 대략 두 배 정도 된다. 심실의 Purkinje계 같은 특수전도 구조물은 심방에는 존재하지 않는다는 게 통설이며, 심방 내 전도가 특별히 어느 방향으로 잘 전도되는 것은 심방 근육속이 해부학적으로 일정한 방향성을 갖고 anisotropy 전도를 함으로써 이해할 수 있다. 이러한 특성은 특히 우심방에 현저하고 좌심방은 상대적으로 균일한 전도 특성을 갖는다. 심방중격의 전도는 더욱 복잡하다. 발생학적으로 심방중격은 중격의 우측과 좌측이 달라 그 사이에 결합조직, 지방조직, 혈관 등으로 나누어져 있고, 따라서 개의 심방 내 한 곳에서도 좌측 심방이 우측에 비해 $10 \mathrm{~ms}$ 정도 늦게 활성화된다.

동방결절을 나온 전기파가 전 심방을 탈분극시키는 현상이 심전도 상 $\mathrm{P}$ 파에 해당하며 시간적으로는 80-100 ms가 소요된다. $\mathrm{P}$ 파가 전심방의 탈분극이라는 점을 고려하면 $\mathrm{P}$ 파의 전반부는 주로 우심방, 후반부는 주로 좌심방, 중앙부는 우, 좌심방 전도파의 중첩에 해당한다. 승모판막 질환에서와 같이 좌심방이 확장하는 경우 $\mathrm{P}$ 파의 폭이 넓어지고 $\mathrm{P}$ 파의 전후반부가 갈라지며 $\mathrm{P}$ 파의 notching이 생기는 P-mitrale이 보이게 된다. 우심방이 확장되면 II 유도에서 $\mathrm{P}$ 파의 크기는 2 $\mathrm{mm}$ 이상으로 커진다. 심조율의 정상, 비정상을 판단할 때 전기파의 근원이 동방결절 여부임을 심전도로는 인지하기가 불가능하므로 사실상 $\mathrm{P}$ 파로 판단할 수밖에 없다. 정상
동조율로 판단하는 조건은 $\mathrm{P}$ 파의 정상 축 $(0-+90$ 도 $)$, 일정하고 정상 범주(120-200 ms)인 PR 간격, 일정한 P파의 모양, 적정 횟수(분당 60-100회) 등을 들 수 있다. P파의 모양은 중요한 판단기준이나 정상의 경우에도 동방결절 내에서 향도잡이 세포의 이동이 생기거나 동일 향도잡이 세포임에도 불구하고 심방으로의 출구가 달라지는 경우 $\mathrm{P}$ 파의 모양이 달라질 수 있으므로 판단에 주의를 기울여야 한다. ${ }^{4}$

\section{2) 방실전도계의 전기흐름}

심방중격에 도착한 전기파는 40-60 ms에 걸쳐 방실결절에 도착한다. 방실결절 상단의 세포에 전기가 도달하는 시각은 $\mathrm{P}$ 파 종료 후가 아니라 $\mathrm{P}$ 파의 중간에 해당한다. 이는 심전도로는 인지가 불가능하며 His속 전기도 상 $\mathrm{A}$ 파의 직후에 해당된다. 방실결절의 총 전도 시간은 $50-70 \mathrm{~ms}$ 정도로 이는 자율신경계의 영향을 많이 받는다. His속 전기도 상의 $\mathrm{AH}$ 간격을 흔히 방실결절전도시간으로 말하나 엄밀히 $\mathrm{AH}$ 간격은 방실결절에 인접한 심방으로부터 His속에 탈분극 파가 도달하는 시간으로 60-125 ms 정도이다. 뒤 이어 His 속에 전도가 이루어지는 시간이 10-25 ms이고 이 시간을 포함하여 좌우각, Purkinje속의 종단까지 전도되는 시간인 $\mathrm{HV}$ 간격은 길이에 비해 매우 빠른 35-55 ms이다. 방실결절 상단의 세포로부터 방실결절과 뒤이은 His-Purkinje계의 탈분극은 심전도 상에 어떠한 파형도 형성하지 못한다. 이 결과 P파 후에 심실의 탈분극 파인 QRS 파가 나타날 때까지 실제와 달리 심전도는 조용한 모습을 띤다.5,6

방실결절은 심방중격 하부의 Koch 삼각형 내에 위치하고 주위의 심근세포와 판이한 형태학적 모습과 활동전위를 갖는다. 방실결절의 세포는 전기생리학적으로 균일하지 않은 6 종류의 세포로 구성되어 있다. 방실결절의 세포들은 일반적으로 늦은 upstroke velocity와 낮은 amplitude를 갖고 전도속도가 늦으며, 율 의존적(rate dependent)인 특성을 갖고 있다. 극단적으로 심방에서 내려오는 자극이 매우 빠를 때는 전도시간이 점차 길어지다 전도차단이 오고, 반면에 동방결절에서 자극형성이 안될 때는 자동능을 가질 수 있는 능력을 발휘한다. 이 세포들은 다른 심장세포에 비해 더 높은 역치전류(threshold current)가 필요하며, 흥분회복이 활동전위의 재분극기를 벗어나야 가능해지는 독특한 
재분극후 불응성(postrepolarization refractoriness) 현상을 갖는다. 빠른 자극 시에 이 현상은 더욱 심해지며 누적되어 방실결절에 독특한 '피로' 현상이 생겨난다. 방실결절의 이러한 특성은 상부, 즉 심방에서 과도히 빠른 자극을 보낼 때 심실을 보호하고 심실이 충만할 수 있는 시간적 여유를 갖게 한다. 방실결절을 구성하는 여러 종류의 세포는 약간 서로 다른 성상을 가지므로 이온이동에 관하여도 이견이 존재한다. 방실결절세포의 탈분극에는 동방결절과 마찬가지로 $\mathrm{L}^{\text {형 } \mathrm{Ca}^{2+}}$ 전류 $\left(I_{\mathrm{Ca}}\right)$ 와 $\mathrm{I}_{\mathrm{f}}$ 가 중요하며, 동방결절과 달리 $\mathrm{Na}^{+}$전류 $\left(I_{\mathrm{Na}}\right)$ 도 소폭으로 활동전위 초기에 작용한다고 알려져 있다. 재분극에는 지연 rectifier current $\left(I_{\mathrm{K}}\right)$, 일시적 외향성 $\mathrm{K}$ 전류 $\left(I_{\mathrm{To}}\right)$ 등이 작용한다. ${ }^{7}$

방실결절을 벗어난 전류는 길이가 $10 \mathrm{~mm}$ 내외인 His속을 거쳐 좌우 bundle branch로 전도되며 복잡한 망을 구성하는 Purkinje속에 도달한다. Purkinje속은 직경 70-80u로서 심장에서 가장 폭이 넓은 세포로 초당 1-4 $\mathrm{m}$ 의 전도속도 역시 가장 빠르다. 체표 심전도로는 인지가 불가능하나 심장 내에 위치시킨 전극도자로는 His속, 우각 및 좌각의 전기도를 확인할 수 있다.

\section{3) 심실의 전기흐름}

Purkinje속은 복잡한 망을 구성하며 심내막 하에 분포하므로 양 심실의 내막 쪽의 세포로부터 활성화되어 심외막 쪽으로 퍼져나가며, 이 속도는 초당 0.3-0.4 m로 늦다. 심실 중에서 가장 먼저 활성화되는 부위는 심실중격과 유두근으로서 심실중격은 중격의 양 표면으로부터 중앙을 향해 활성화된다. 중격이 먼저 수축해 단단해짐으로써 후에 수축할 양 심실의 축역할을 하고 유두근의 조기수축은 심실수축 시 방실판막의 외번(eversion)을 방지하는 역할을 한다. 우심실벽이 좌심실에 비해 얇으므로 우심실의 탈분극이 먼저 종료되며 양심실의 기저부에 비해 심첨부와 중앙부위가 먼저 활성화된다. 가장 늦게 활성화되는 부위는 기저부 후면의 심외막하 심실부위이다. 전 심실이 탈분극을 마치는 데 드는 시간은 60-100 ms이고 이는 심전도 상의 QRS 폭에 해당된다.

심실을 구성하는 심실세포는 국소에 따라 약간 다른 전기생리학적 성질을 갖고 있는데, 심외막 쪽의 세포는 활동전위 1 기와 2 기 사이에 notch가 생기는 spike-and- dome 모양을 갖는다. 이 현상은 $\mathrm{K}^{+}$에 의한 일시적 외향성 전류(transient outward current, $I_{\mathrm{to}}$ )에 의한다. 이로 인해 $1000 \mathrm{~ms}$ 주기를 경계로 자극주기가 짧을 때는 심외막 쪽의 세포가 심내막쪽에 비해 상대적으로 활동전위기간(action potential duration, $\mathrm{APD}$ )이 짧아지고 자극주기가 길 때는 $\mathrm{APD}$ 가 길어지는 양상을 보인다. 또 $I_{\mathrm{to}}$ 가 회복됨으로써 활동전위 진폭이 커짐에 따라 supernormal conduction이 심외막 세포에서 가능하게 하고 Osborne 파를 형성하게 한다. 심실 벽의 중간 층에 있는 세포는 여타 세포와 다른 전기적 성질을 지니고 있어 구분되는데, 이를 $\mathrm{M}$ 세포로 부른다. 이 $\mathrm{M}$ 세포는 좌심실 벽의 $40 \%$ 정도를 차지하며, spike-and-dome 모양을 갖고 매우 긴 APD가 특징적이다. $\mathrm{M}$ 세포들은 여러 약제에 반응하여 활동전위를 심하게 연장시키고 후탈분극과 triggered activity를 잘 발생시킨다고 알려져 있다. 8.9

\section{4) 흥분성 회복}

심방과 심실의 근육세포는 주로 $I_{\mathrm{Na}}$ 에 의해, 동방결절은 $I_{\mathrm{Ca}}$ 와 $I_{\mathrm{f}}$ 에 의해 흥분되며, 또한 방실결절은 $I_{\mathrm{Ca}}, I_{\mathrm{f}}$, 소량의 $I_{\mathrm{Na}}$ 에 의해 흥분됨은 앞에서 서술한 바와 같다. 일단 탈분극된 여러 세포들은 다음 주기의 탈분극에 대비하기 위해 흥분성을 회복하는 과정인 재분극이 필수적이다. 재분극은 탈분극에 비해 서서히 발생하여 수축기와 이완기의 적절한 시간적 배분이 가능하게 하고 다음 수축의 수축력과 전도속도 결정에 중요한 역할을 한다. 빠른 속도로 탈분극을 일으키는 $\mathrm{Na}^{+}$와 $\mathrm{Ca}^{2+}$ 전류와 달리 천천히 지연되어 활성화되는 재분극 전류는 주로 외향성 $\mathrm{K}^{+}$전류에 의하며 이런 성질로 인하여 delayed rectifier current라고 불린다. ${ }^{10}$

탈분극 시와 같이 동방결절, 방실결절을 포함한 전도계의 재분극 시에도 심전도로 인지가 가능한 어떠한 파형도 형성하지 못한다. 심방의 재분극은 $\mathrm{Ta}$ 파를 형성하나 진폭이 매우 적고 시간적으로 $\mathrm{QRS}$ 파와 거의 같은 시각에 발생하기 때문에 통상적인 심전도에서 확인이 거의 불가능하다. 심실의 재분극은 일반적으로 탈분극의 방향과 반대인 심외막으로 부터 심내막 쪽으로 향한다고 알려져 있고, 심전도 상 T파를 형성한다. 심전도 상의 QT 간격은 전 심실의 탈분극으로부터 재분극이 종료하는 시점까지의 간격으로 거의 대부분의 시간을 재분극이 차지한다. 재분극을 관찰할 수 있는 도구가 
multifocal atrial tachycardia (MAP)와 QT 간격 외에 별로 없으므로 $\mathrm{QT}$ 간격 측정과 12 유도에서 측정한 $\mathrm{QT}$ 간격의 차이를 구하는 QT 간격 분산(QT dispersion)은 측정 방법 상의 문제점에도 불구하고 재분극 현상 연구에 훌륭한 수단으로 사용되고 있다.1112

\section{심전도파의 생성원리와 기록13,14}

\section{1) 심전도파의 생성원리}

가로로 누워있는 긴 원통형의 단일심근세포가 있다고 가정하고 탈분극의 과정을 살펴보자. 분극이 유지된 심근세포는 바깥쪽이 양의 전기, 안쪽이 음의 전기를 띄고 있다. 원통의 왼쪽에서 탈분극이 일어나 오른쪽 방향으로 퍼져간다고 할 때 왼쪽 끝 부분에서 세포 내로 양의 전기가 흘러 들어오고, 바깥쪽은 음이 된다. 세포 내 양의 전기는 오른쪽 방향으로 퍼져서 우측 끝에 도달하면 심근세포 전체에 탈분극이 이루어진 것이다. 이 때 양의 전기가 흘러가는 방향은 좌측에서 우측이 된다. 만약 심전도 유도가 원통의 우측 끝에 있다면, 양의 전기는 유도로 오는 방향이 되고, 좌측 끝에 있다면 유도에서 멀어지는 방향이 된다. 심전도는 양의 전기가 올 때 위로 올라가고, 멀어질 때 내려가는 그래프를 그린다. 만약 원통의 가운데에 유도가 있다면 양의 전기는 유도 쪽으로 오다가 지나쳐서 멀어지게 된다. 이 때 심전도는 처음에는 올라가고 이어서는 내려가는 이상성 (biphasic) 그래프를 그린다.

이번에는 재분극 과정을 같은 모델로 살펴보자. 심장의 탈분극은 내막에서 외막으로 향하지만 재분극은 외막에서 내막의 순서로 이루어지므로 단일심근세포 모델에서도 재분극은 우측에서 좌측으로 일어나는 것으로 가정한다. 재분극은 세포 내 양의 전기가 음으로 바뀌는 것으로 시작한다. 음의 전기는 왼쪽으로 퍼져서 좌측 끝에 도달하면 재분극이 마무리된다. 이 때는 음의 전기가 이동하므로 유도에서 가까워지면 심전도 그래프는 아래로 내려가고 멀어지면 올라간다. 따라서 원통 우측에 있는 유도에서는 올라가고 좌측의 유도에서는 내려간다. 탈분극은 His속과 Purkinje속 등 특화된 전도계를 통해 전도되므로 빠르지만 재분극은 그렇지 않아 속도가 두 배 이상 느리다. 따라서 심전도에서 심실근육의 탈분극을 의미하는 $\mathrm{QRS}$ 는 폭이
좁고, 재분극을 나타내는 T파는 폭이 넓다.

\section{2) 심전도유도의 기록 방법}

심전도계는 사지와 흥부에 부착한 전극에서 전위를 기록한다. 전위의 절대값은 보여주지 않고, 양쪽 유도의 전위차만을 기록하여 그래프로 나타낸다. 심장의 전기적인 활동은 크기와 방향을 가지고 있기 때문에 벡터(vector)라고 부른다. 또한 전기적인 활동의 진행방향을 전기축(electrical axis)으로 부른다. 심전도의 기록은 극을 몇 개를 이용하느냐에 따라 단극 또는 쌍극유도로 나누고, 심장을 관상면(coronal plane)으로 보는 사지유도와 수평면 (transverse plane)으로 보는 흉부유도로 구분한다. 사지유도는 오른팔, 왼팔, 왼발에 전극을 부착하고, 흥부유도는 전 흥부에 전극을 부착하여 기록한다. 오른발에 연결하는 전극은 참조용이고 노이즈를 줄이기 위해 사용한다.

\section{3) 쌍극유도와 단극유도}

쌍극유도는 두 지점 사이의 전위차를 기록한 것이다. 표준 12 유도 가운데 사지유도 I, II, III만이 쌍극유도이다. 예를 들어 유도 I의 경우 왼팔과 오른팔의 전위차를 기록하는데, 오른팔은 음극, 왼팔은 양극으로 설정하여 기록한다. 유도 I, II, III은 삼각형을 이루어 벡터는 I과 III의 합이 II가 된다. 이를 Einthoven의 법칙이라고 부른다.

단극유도는 기준점을 두고 이 기준점으로부터 보고자 하는 탐색 전극의 전위차를 기록하는 방법이다. 따라서 엄밀히 말하면 한 개의 극만으로 기록할 수 있는 것은 아니다. 기준이 되는 전극은 윌슨의 중심단자(Wilson's central terminal)라고 부른다. 윌슨의 중심단자는 오른팔, 왼팔, 왼발에 연결된 전극선을 모두 하나로 연결하여 만든다. 이 가상의 전위를 기준점 영으로 정하고, 이 기준점과의 전위차를 기록하는 것이 단극유도이다. 윌슨의 중심단자는 심장주기 동안 전위가 비교적 일정하기 때문에 기준점으로 이용할 수 있다. 사지유도에서는 유도 I, II, III을 제외한 VR, VL, VF가 단극유도이다. 흉부유도는 $\mathrm{V}_{1-6}$ 가 모두 단극유도이다. 사지유도의 $\mathrm{VR}, \mathrm{VL}, \mathrm{VF}$ 는 기록되는 유도를 제외한 나머지 두 유도로 기준점을 정한다. 그렇게 하는 이유는 기록되는 자신의 유도가 포함되는 경우 진폭이 줄어들기 때문이다. 
자신의 유도를 제외하는 경우 이론적으로 진폭이 $50 \%$ 정도 커지는데, 표준유도에서는 이렇게 증폭된(augmented) 값을 사용하기 때문에 $\mathrm{aVR}, \mathrm{aVL}, \mathrm{aVF}$ 로 부른다.

\section{4) 사지유도와 흉부유도}

표준 사지유도 6 개는 3 개의 쌍극유도(I, II, III)와 3 개의 단극유도 $(\mathrm{aVR}, \mathrm{aVL}, \mathrm{aVF})$ 로 구성된다. 쌍극유도 $\mathrm{I}$ 은 오른팔에 음극을, 왼팔에 양극을 붙이고, II는 오른팔에 음극을, 왼발에 양극을, 피는 왼팔에 음극을, 왼발에 양극을 붙인다. 단극 사지유도인 $\mathrm{aVR}, \mathrm{aVL}, \mathrm{aVF}$ 는 자신을 제외한 나머지 두 유도를 음극으로 삼고, 탐색 단자를 각각 오른팔, 왼팔, 왼발에 붙여 기록한다.

흉부유도 6 개는 모두 단극유도이다. 따라서 윌슨의 중심단자가 기준이 되고 가슴 벽에 붙이는 각각의 전극이 탐색 전극이 된다. 흥부유도 전극의 부착 위치는 $\mathrm{V}_{1}$ 은 4 번째 늑간 오른쪽 흉골 경계선, $\mathrm{V}_{2}$ 는 4 번째 늑간 왼쪽 흉골 경계선, $\mathrm{V}_{4}$ 는 5 번째 늑간 왼쪽 쇄골 중간선, $\mathrm{V}_{3}$ 는 $\mathrm{V}_{2}$ 와 $\mathrm{V}_{4}$ 의 중간지점, $\mathrm{V}_{5}$ 는 $\mathrm{V}_{4}$ 와 수평위치의 겨드랑이 앞선, $\mathrm{V}_{6}$ 는 $\mathrm{V}_{4}$ 와 수평위치 겨드랑 중간선이다. 흥부유도 $\mathrm{V}_{1-2}$ 는 우심방과 우심실, $\mathrm{V}_{5-6}$ 은 좌심실, $V_{3-4}$ 는 심실중격에 접하고 있어 해당 지역의 병변을 잘 반영한다.

우심실경색을 진단하기 위해 우흥부유도를 찍기도 하는데, $\mathrm{V}_{4}$ 와 $\mathrm{V}_{5}$ 를 대칭이 되는 우측에 붙여 기록하고 $\mathrm{V}_{4} \mathrm{R}, \mathrm{V}_{5} \mathrm{R}$ 로 명명한다. 또한, 좌심실 후벽경색을 보다 정확히 진단하기 위해 $V_{7-9}$ 유도(후흉부유도)를 사용하기도 한다. $V_{7}$ 은 뒤 겨드랑선에, $\mathrm{V}_{8}$ 은 뒤 견갑골선에, $\mathrm{V}_{9}$ 은 척추 왼쪽 경계선에 붙여서 기록한다. $V_{7-9}$ 의 수평선은 모두 $V_{4}$ 와 같은 위치다.

\section{5) 심전도 기록 방법}

심전도는 $1 \mathrm{~mm}$ 간격의 가는 선과 $5 \mathrm{~mm}$ 간격의 굵은 선이 새겨진 모눈종이에 기록된다. 표준 기록 속도는 초당 $25 \mathrm{~mm}$ 이며, 표준 전위 증폭 비는 $\mathrm{mV}$ 당 $10 \mathrm{~mm}$ 이다. 따라서 가로 눈금 1개 $(1 \mathrm{~mm})$ 는 0.04 초 $(40 \mathrm{~ms})$ 이고, 세로 눈금 1개 $(1 \mathrm{~mm})$ 는 $0.1 \mathrm{mV}$ 이다. 심전도를 판독할 때 폭이 넓거나 전위가 높으면 기록 속도와 전위 비가 표준에 맞게 기록되었는지 반드시 확인해야 한다.

\section{결론}

심전도는 발명된 지 100년이 넘는 동안 심장의학의 발전에 커다란 기여를 해왔다. 심박동기의 사용, implantable cardioverter-defibrillator (ICD)의 개발, 개심술의 발전, 심인성 급사의 이해, 허혈성 심질환 연구의 발전 등은 심전도에 대한 새로운 관심을 일으키고 심전도의 영역을 넓혔다. 심전도 이후에 개발된 심장의 전기현상을 연구할 수 있는 여러가지 방법들이 있다. 생활심전도, 운동부하심전도, signal averaged ECG, 컴퓨터분석 심전도, 3차원 임상 전기생리학검사, 전극도자절제술, surface mapping 등 역시 심전도의 지식을 크게 하고 적용반경을 크게 하였다. 현재의 심전도는 전통적이고 간편하며 정밀한 심장 진단의 도구로서 위의 새로운 방법들과 더불어 광의의 심전도로 계속 발달될 것이다. ${ }^{15}$

\section{References}

1) Fye WB. Disorders of the heartbeat: A historical overview from antiquity to the mid-20th century. Am J Cardiol. 1993;72:10551070.

2) Fisch C. Evolution of the clinical electrocardiogram. J Am Coll Cardiol. 1989;14:1127-1138.

3) Michaels DC, Matyas EP, Jalife L. Mechanisms of sinoatrial pacemaker synchronization: a new hypothesis. Circ Res 1987;61:704-714.

4) Schuessler RB, Boineau JP, Bromberg BI, et al: Normal and abnormal activation of the atrium: In Cardiac Electrophysiology (ed. Zipes DP and Jalife J) 543, 1995.

5) Berne MB, Levy MN. Electrical activity of the heart. In Cardiovascular Physiology 5, 1981

6) Josephson ME. Electrophysical investigation. In Clinical Cardiac Electrophysiology 5, 1993

7) Billete J, Metayer R, St-Vincent M. Selective functional characteristics of rate-induced fatigue in rabbit atrioventricular node. Circ Res. 1988;62:790-799.

8) Litvosky SH, Antzelevitz C. Tansient outward current prominent in canine ventricular epicardium but not endocardium. Circ Res. 1988;62:116-126.

9) Sicouri S, Antzelevitz C. A subpopulation of cells with unique 
electrophysiological properties in the deep subepicardium of the canine ventricle. The M cell. Circ Res. 1991;68:1729-1741

10) Jose A, Sanchez-Chapula, Marcel AG. Molecular regulation of cardiac inward rectifier potassium channels by pharmacologic agents: In Cardiac Electrophysiology (ed. Zipes DP and Jalife J) 6, 2014.

11) Franz MR. Long-term recording of monophasic action potentials from human endocardium. Am J Cardiol. 1983;51:1629-1634.

12) Han HJ, Rho TH, Lee MY, Kim HY, Youn HJ, Kim JJ, Kim JK, Choi KB, Hong SJ. Change of QT dispersion following successful percutaneous transluminal coronary angioplasty (PTCA). Korean JMed. 1997;52:780-785.

13) 김지훈. 비침습적 검사. 부정맥. 대한심장학회 부정맥연구회. 2012.

14) 노태호. 심전도의 구성. 노태호의 알기 쉬운 심전도 6 . 2013.

15) Tanaka Y, Huang SS, Gerstenfeld EP. Advanced Catheter ThreeDimensional Mapping Systems. In Catheter Ablation of Cardiac Arrhythmias 3, 2015. 